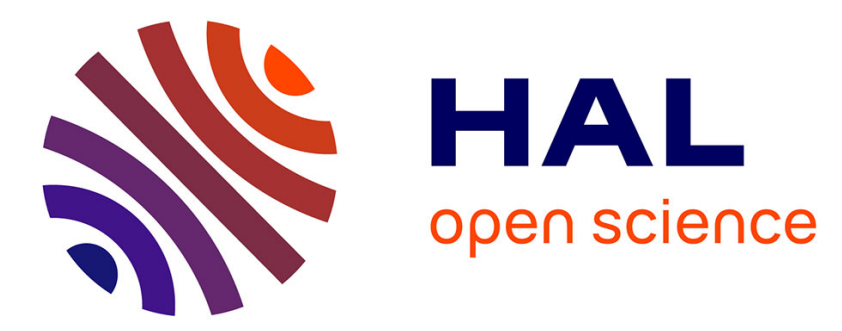

\title{
An Up-to-Date Technologies Review and Evaluation of Wave Energy Converters
}

\author{
Hosna Titah-Benbouzid, Mohamed Benbouzid
}

\section{To cite this version:}

Hosna Titah-Benbouzid, Mohamed Benbouzid. An Up-to-Date Technologies Review and Evaluation of Wave Energy Converters. INTERNATIONAL REVIEW OF ELECTRICAL ENGINEERING-IREE, 2015, 10 (1), pp.52-61. 10.15866/iree.v10i1.5159 . hal-01153767

\section{HAL Id: hal-01153767 https://hal.science/hal-01153767}

Submitted on 20 May 2015

HAL is a multi-disciplinary open access archive for the deposit and dissemination of scientific research documents, whether they are published or not. The documents may come from teaching and research institutions in France or abroad, or from public or private research centers.
L'archive ouverte pluridisciplinaire HAL, est destinée au dépôt et à la diffusion de documents scientifiques de niveau recherche, publiés ou non, émanant des établissements d'enseignement et de recherche français ou étrangers, des laboratoires publics ou privés. 


\title{
An Up-to-Date Technologies Review and Evaluation of Wave Energy Converters
}

\author{
Hosna Titah-Benbouzid $^{1}$ and Mohamed Benbouzid ${ }^{1}$
}

\begin{abstract}
The potential of electric power generation from marine renewable energy is enormous. Ocean waves are being recognized as a resource to be exploited for the sustainable generation of electrical power. The high load factors resulting from the fluid properties and the predictable resource characteristics make ocean waves particularly attractive for power generation and advantageous when compared to other renewable energies. Regarding this emerging and promising area of research, this paper presents a complete review of wave energy technologies describing, analyzing and fixing many of the concepts behind wave energy conversion. The proposed review will specifically highlights the main wave energy conversion projects around the world at different levels (demonstration stage, in production, and commercialized projects). In particular, mooring will be discussed, as it is a key feature behind massive deployment of wave energy converters. Finally, a discussion will highlight challenges that wave energy converters need to overcome to become commercially competitive in the global energy market. Copyright (C) 2015 Praise Worthy Prize S.r.l. - All rights reserved.
\end{abstract}

Keywords: Marine renewable energy, wave energy converter, design, challenges.

\section{Nomenclature}

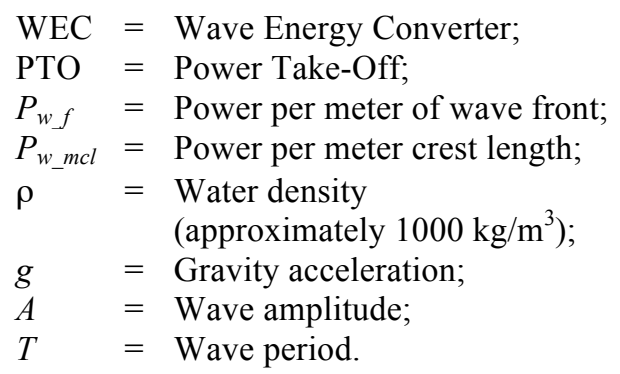

\section{Introduction}

One of the very attractive renewable energy sources is the ocean. Indeed, it covers around three quarters of the earth surface and energy can be extracted from the waves, tides, currents, temperature gradients, and salinity gradients. Wave energy, in particular, is spatially more concentrated than both wind and solar energy; it is also more persistent and predictable than wind energy. The global wave power resource has been estimated to be at least $1 \mathrm{TW}$, with a potential annual energy production of about $2000 \mathrm{TWh}$; this is comparable to the energy production from nuclear or hydropower [1-4].

The history of wave power research spans over more than two hundred years. The Frenchman Pierre-Simon Girard is recognized as the first holder of a wave power patent in 1799 [5] (Fig. 1a). Yoshio Masuda may be regarded as the father of modern WEC technology, with studies in Japan since the 1940s. He developed a navigation buoy powered by wave energy, equipped with an air turbine, which was in fact what was later named as a (floating) oscillating water column (Fig. 1b).

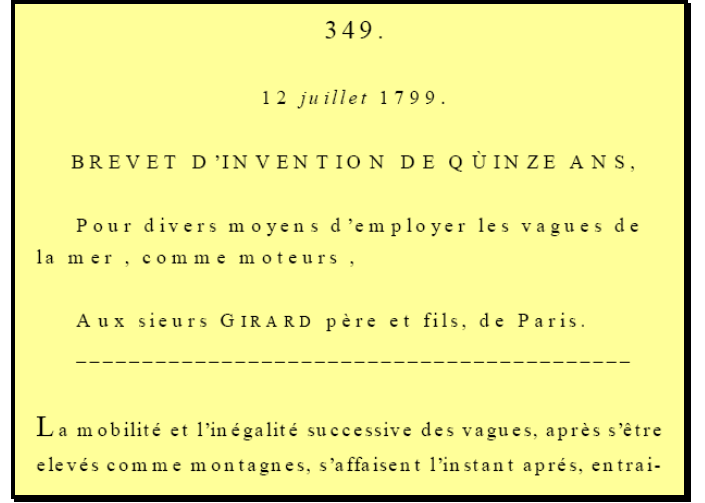

(a) Pierre-Simon Girard WEC patent.

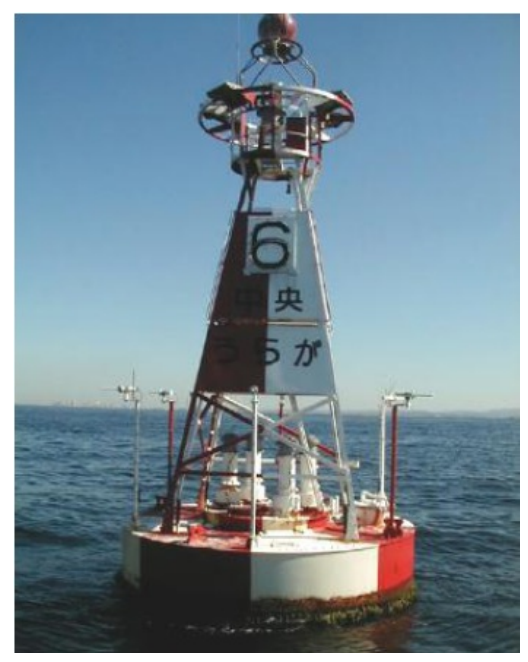

(b) Yoshio Masuda oscillating water column.

Fig. 1. WEC history review. 
These buoys were commercialized in Japan since 1965 (and later in USA) [6]. Since then many different other concepts have been conceived. Some of these have come no further than the drawing table, others have made it into small-scale models, and a few have also moved on to ocean testing. The technology is still immature and would not commercially exist if governments did not subsidize it. Therefore, to become a competitive market, it is crucial for the industry to reduce the overall cost of electricity generated from waves. There are many different WEC technologies, and it is not clear which one is superior. WECs developers tend to focus on the prime-mover aspect and use off-the-shelf electrical systems to generate electrical power. These electrical systems usually include a gearbox or a hydraulic system to interface a slow moving prime mover to a conventional high-speed rotary machine. The use of gearboxes or hydraulics introduces potential extra-scheduled and unscheduled maintenance costs. Moreover, the maintenance for offshore devices is much more expensive than onshore equivalents and limited by weather conditions, which results in increased downtime costs.

The present review aims at giving an update of the most recent trends regarding main wave energy conversion projects around the around at different levels (demonstration stage, in production, and commercialized projects) with respect to overviews already published in the past years [6-13]. In particular, mooring will be discussed, as it is a key feature behind massive deployment of wave energy converters. Finally, a discussion will highlight challenges that wave energy converters need to overcome to become commercially competitive in the global energy market.

\section{Wave Energy Background}

Figure 2 show an atlas of the global power density distribution of the oceans. The north and south temperature zones have the best sites for capturing wave power. The prevailing winds in these zones blow strongest in winter. Increased wave activity is found between the latitudes of $30^{\circ}$ and $60^{\circ}$ on both hemispheres, induced by the prevailing western winds blowing in these regions.

A wave resource is typically described in terms of power per meter of wave front (wave crest length) [8].

$$
P_{w_{-} f}=\frac{1}{8 \pi} \rho g^{2} A^{2} T
$$

It can also be described in terms of wave power per meter crest length $\left(P_{w_{-} m c l}\right)$.

$$
P_{w_{-} m c l}=\frac{1}{32 \pi} \rho g^{2} H^{2} T
$$

It should be noted that the wave height $H$ is defined as equal to $2 A$ (Fig. 3).

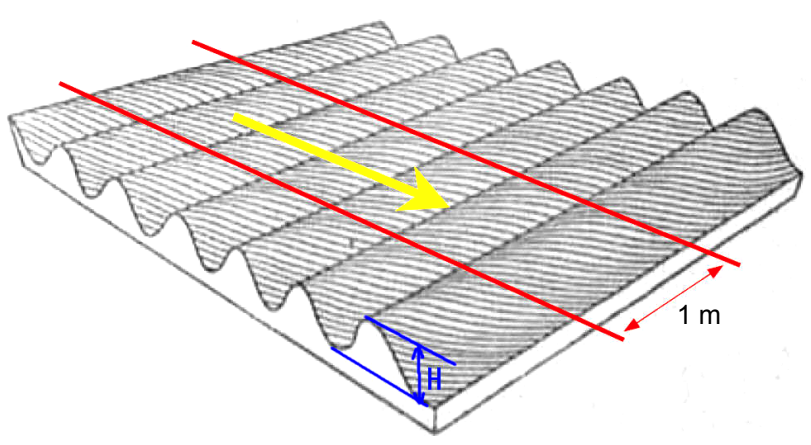

Fig. 3. Wave dimensions.

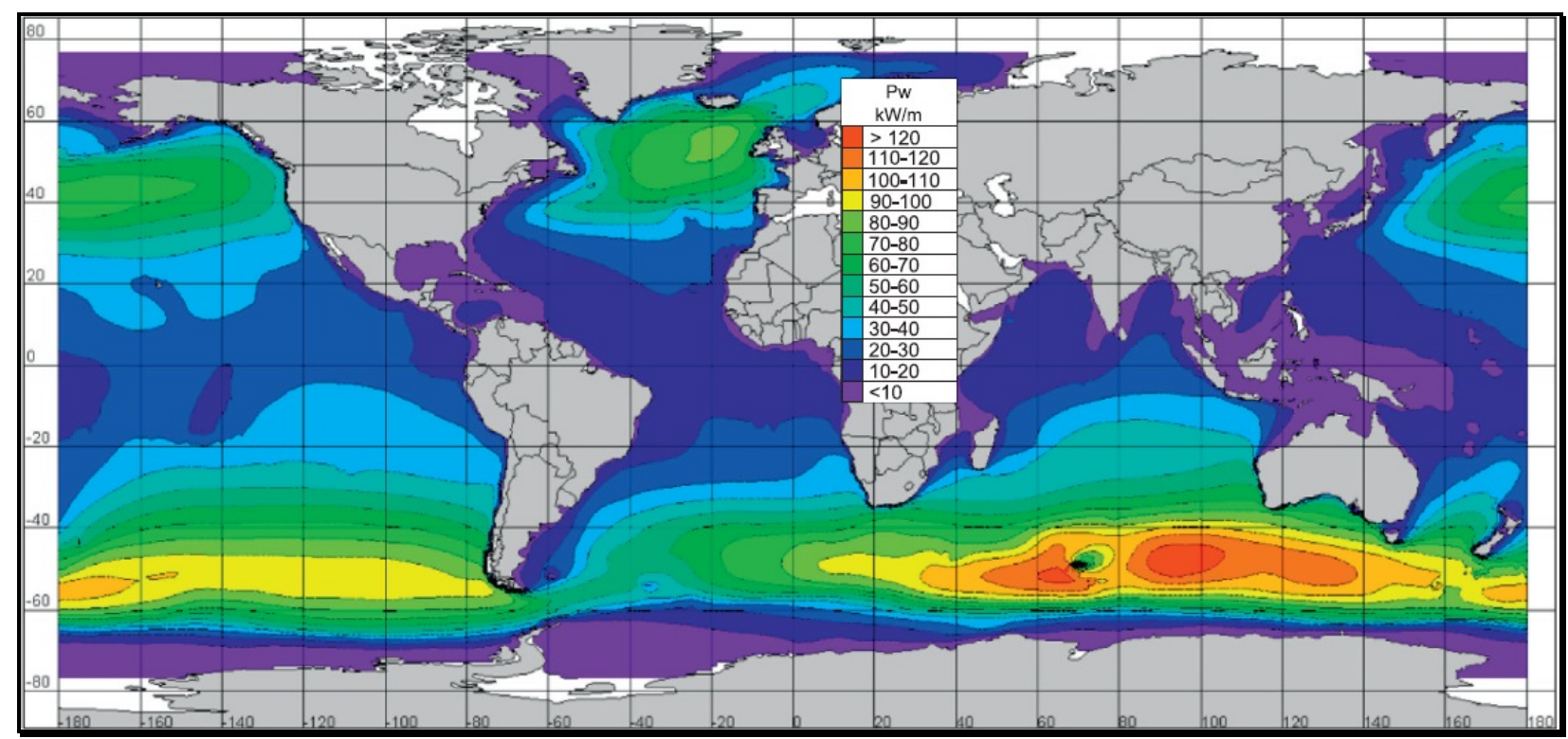

Fig. 2. Global annual mean wave power estimation in $\mathrm{kW} / \mathrm{m}$ spanning 10 years period [10] 


\section{Wave Energy Converters}

\section{III.1. WEC Concepts}

WECs have been developed to extract energy from shoreline out to the deeper waters offshore. These devices are generally categorized by the installation location and the Power Take-Off (PTO) system. Locations are shoreline, near shore and offshore (Fig. 4). In this context, most devices can be characterized as belonging to six types: Attenuator; Point absorber; Oscillating wave surge converter; Oscillating water column; Overtopping device; Submerged pressure differential (Fig. 5).

\section{III.2. WEC Main Projects}

Figure 6 summarizes the main WEC projects in terms of concepts and locations. It should be mentioned that this figure tries to summarize the main and well-known WEC mainly over the demonstration stage. Indeed, there is a large number and variety of WEC that vary in concept and design. In addition to the fact, that there were more than 1000 patents in 2009 [10]. In fact, all of these projects should be considered as in early stages if compared to other renewable technologies (i.e. wind).

In this particular huge developing context, it should be noted a new French WEC project called EM Bilboquet [14-15]. The PTO extracts the mechanical power due to incoming waves by a system made up of a cylindrical buoy sliding along a partially submerged structure (Fig. 7). This structure is made up of a vertical cylinder, referenced in the following as spar, with a damping plate attached at its keel. Energy resulting from the relative motion between the two concentric bodies is harnessed by rack-and-pinion, which drives a permanent magnet synchronous generator through a gearbox [16].

\section{Wave Energy Extraction}

Figure 8 summarizes the different conversion stages. In particular this figure shows that there is a variety of ways to extract power from waves: pneumatically, hydraulically, and mechanically (PTO) [17]. This mechanical interface is used to convert the slow rotational speed or reciprocating motion into high-speed rotational motion for connection to a conventional rotary electrical generator. In this context, attention will be directed at the mechanism needed to convert wave energy into electricity as most building blocks in the generation system remain nearly the same after being transformed into the electrical form [18].

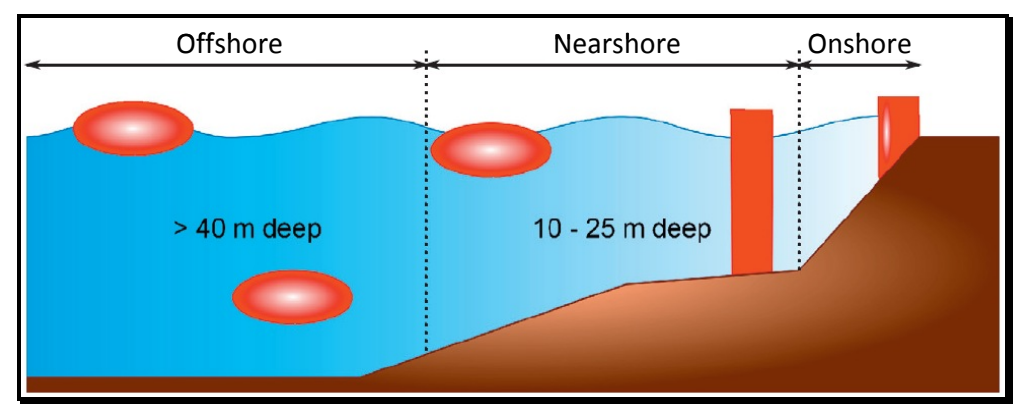

Fig. 4. WECs locations.

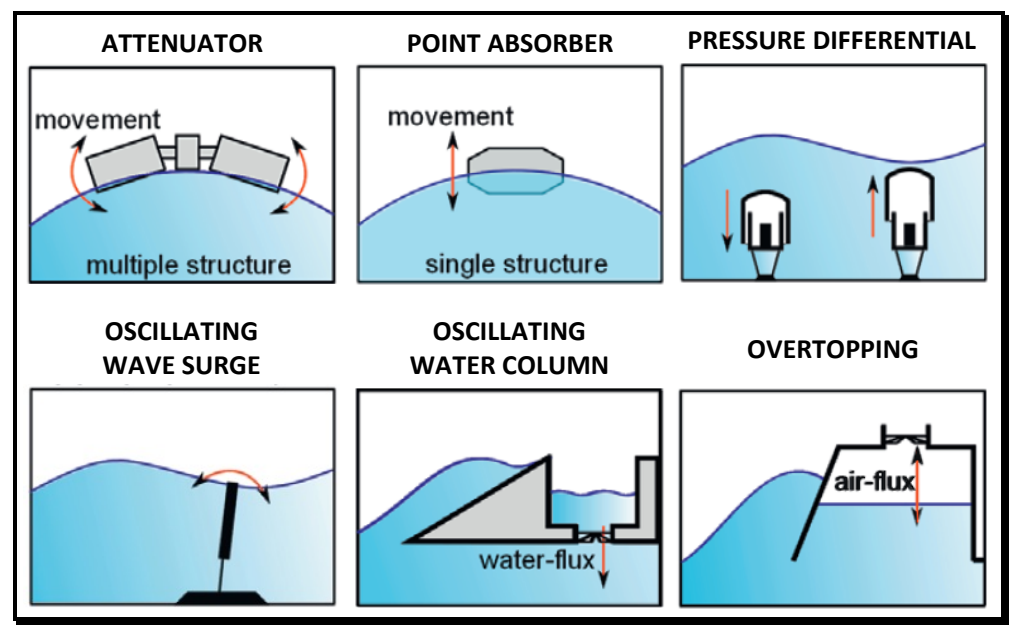

Fig. 5. WECs concepts. 


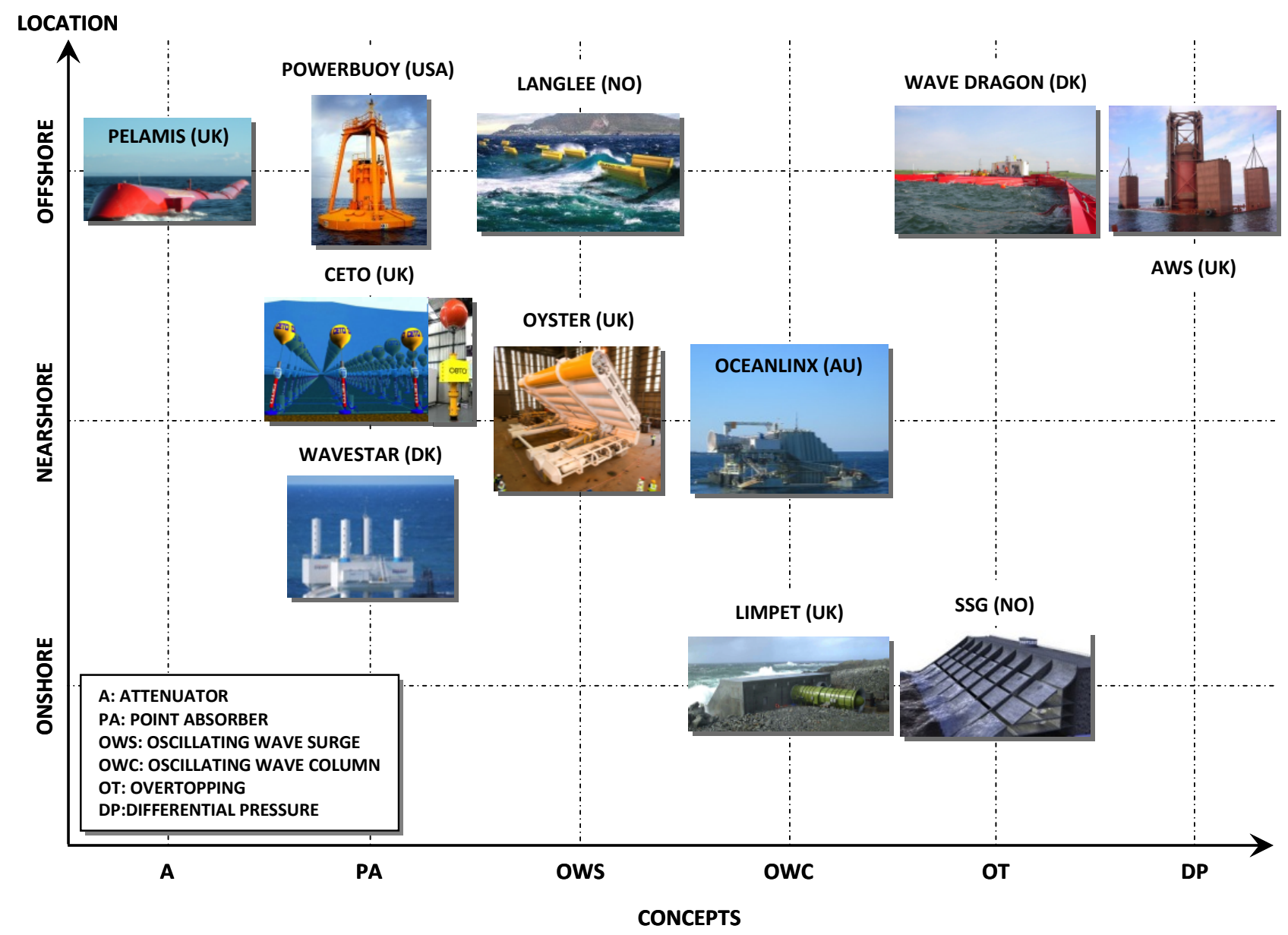

Fig. 6. WECs main projects.
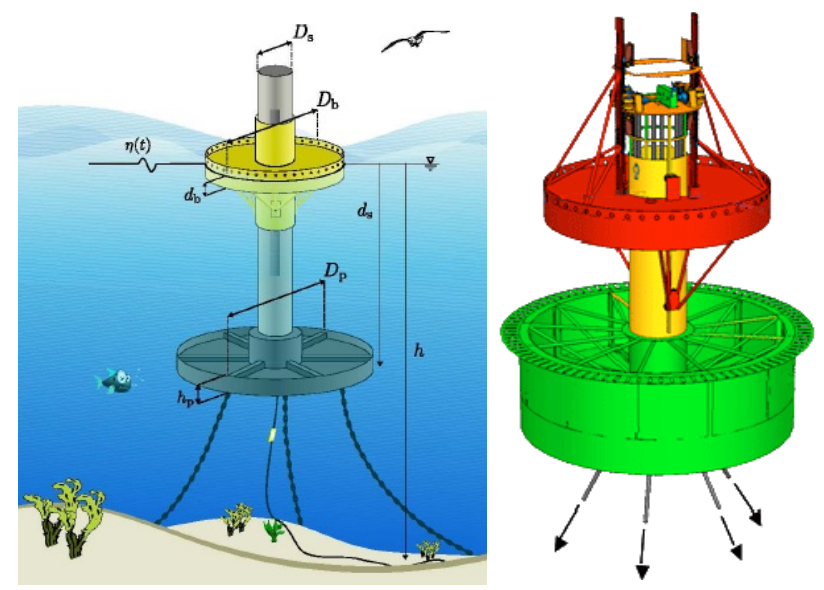

Fig. 7. The EM Bilboquet French wave energy converter.

Linear generators are an option on the testing stage, but they are not yet currently used in most developed WECs [19-24]. In particular, different types of linear generators were investigated for the AWS WECs [2527]. These investigations have led to the conclusion that the transverse flux permanent magnet generator is a good candidate in terms of higher power density and efficiency. The use of permanent magnet synchronous generator is an intermediate option [16], [28]. The use of induction generators implies a specific mechanical PTO that induces additional losses affecting the WEC overall efficiency [29-32]. In this context, there are still mechanical engineering challenges in terms of electrical generator offshore suitability [10], [33]. Table 1 summarizes the PTO systems and the electrical generator options for the some of Fig. 6 WEC projects.

\section{Wave Energy Converter Mooring}

To use wave energy for electricity generation, WECs must be anchored to the seabed and moored by cables (Fig. 9). Similar to other offshore structures moored on the sea floor, a typical WEC mooring system is likely to be composed of three parts: the mooring line, the connectors and the anchor. Chain, wire rope and synthetic fiber rope are the three main mooring line types that are used in offshore structures and could be used for WECs [38-40]. Chains provide good catenary stiffness and are abrasion resistant. However, their restraining stiffness may not be appropriate for some WECs. They can hamper the oscillation motion required to convert energy. Synthetic ropes are advantageous because of their buoyancy property, which will reduce mooring weight influence during normal operation and are good candidates for deep-water applications [41]. 


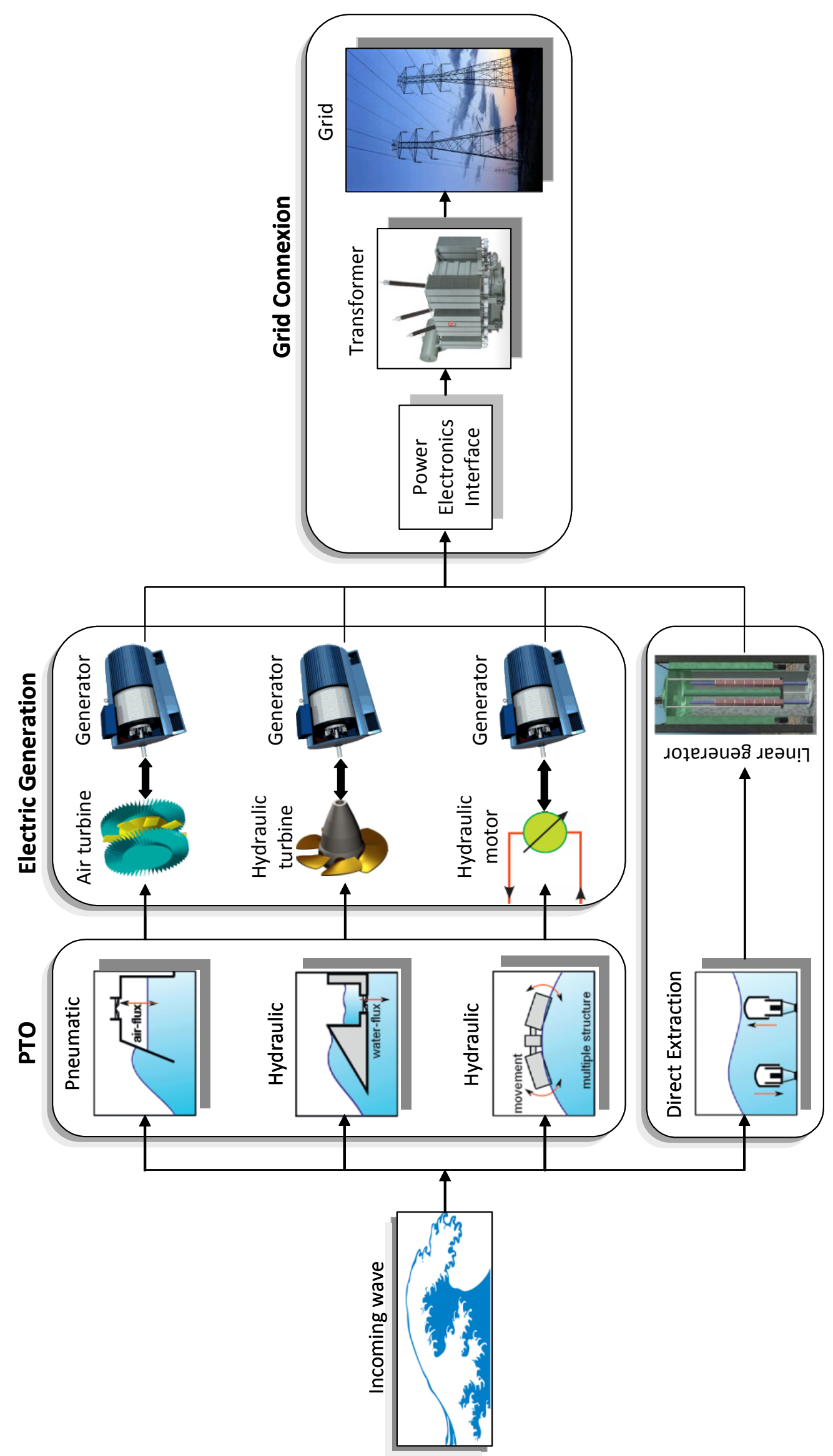

Fig. 8. WEC different type of conversions. 


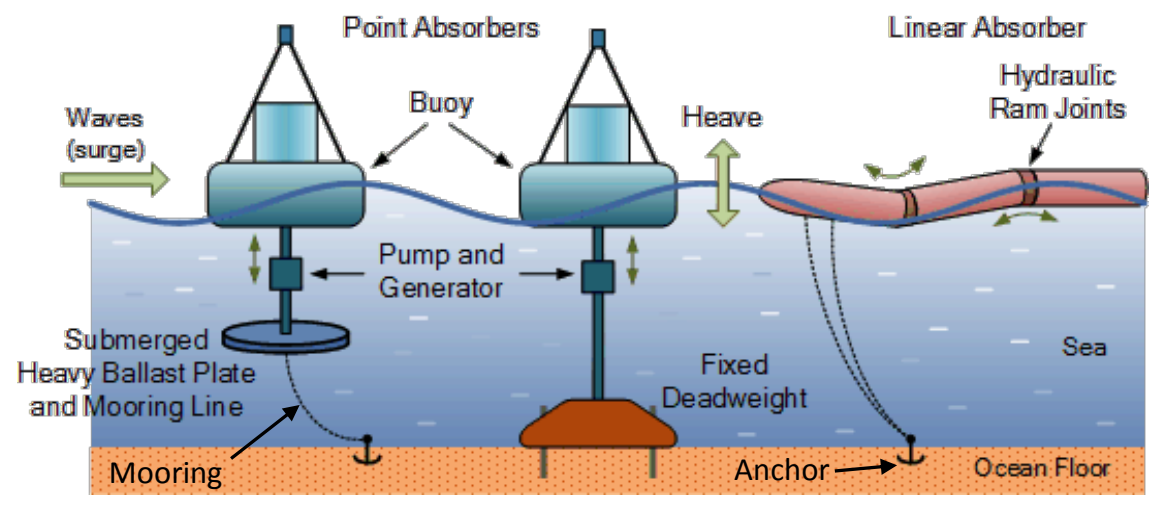

Fig. 9. Wave energy converters mooring and anchor.

TABLE 1. SOME WEC PROJECTS PTOS AND GENERATORS.

\begin{tabular}{|c|c|c|}
\hline WEC & PTO & Generator \\
\hline PELAMIS & Attenuator/Hydraulics & $\begin{array}{l}\text { Cage induction } \\
\text { generator }\end{array}$ \\
\hline POWERBUOY & Point absorber & $\begin{array}{l}\text { Permanent magnet } \\
\text { synchronous } \\
\text { generator }\end{array}$ \\
\hline $\begin{array}{c}\text { WAVESTAR } \\
\text { [34] }\end{array}$ & $\begin{array}{l}\text { Point absorber/ } \\
\text { Hydraulics }\end{array}$ & $\begin{array}{l}\text { Permanent magnet } \\
\text { synchronous } \\
\text { generator }\end{array}$ \\
\hline $\begin{array}{c}\text { SEAREV [5], } \\
{[35]}\end{array}$ & Point absorber & $\begin{array}{l}\text { Permanent magnet } \\
\text { synchronous } \\
\text { generator }\end{array}$ \\
\hline BILBOQUET & Point absorber & $\begin{array}{l}\text { Permanent magnet } \\
\text { synchronous } \\
\text { generator }\end{array}$ \\
\hline OYSTER & $\begin{array}{l}\text { Oscillating wave surge } \\
\text { converter }\end{array}$ & $\begin{array}{l}\text { Cage induction } \\
\text { generator }\end{array}$ \\
\hline $\begin{array}{c}\text { LANGLEE } \\
{[36]}\end{array}$ & $\begin{array}{l}\text { Oscillating wave surge } \\
\text { converter }\end{array}$ & $\begin{array}{l}\text { Permanent magnet } \\
\text { synchronous } \\
\text { generator }\end{array}$ \\
\hline LIMPET & $\begin{array}{l}\text { Oscillating water column } \\
\text { \& Wells turbine }\end{array}$ & $\begin{array}{l}\text { Cage induction } \\
\text { generator }\end{array}$ \\
\hline OCEANLINX & $\begin{array}{l}\text { Oscillating water column } \\
\& \text { Denniss-Auld turbine }\end{array}$ & $\begin{array}{l}\text { Cage induction } \\
\text { generator }\end{array}$ \\
\hline PICO [8] & $\begin{array}{l}\text { Oscillating water column } \\
\text { \& Wells turbine }\end{array}$ & $\begin{array}{l}\text { Doubly-fed } \\
\text { induction } \\
\text { generator }\end{array}$ \\
\hline $\begin{array}{l}\text { WAVE } \\
\text { DRAGON }\end{array}$ & $\begin{array}{l}\text { Overtopping \& Kaplan } \\
\text { turbine }\end{array}$ & $\begin{array}{l}\text { Permanent magnet } \\
\text { synchronous } \\
\text { generator }\end{array}$ \\
\hline SSG [37] & Overtopping & $\begin{array}{l}\text { Permanent magnet } \\
\text { synchronous } \\
\text { generator }\end{array}$ \\
\hline AWS & Direct drive & $\begin{array}{l}\text { Linear permanent } \\
\text { magnet generator }\end{array}$ \\
\hline
\end{tabular}

There are many kinds of connectors used on WECs and other marine structures [38], [42]. Anchors are the terminals that transfer the whole system forces to the seabed.
The two major requirements for a WEC mooring are to withstand the environmental and other loadings involved in keeping the device on station, and to be sufficiently cost-effective so that the overall device economics remain viable. In particular the mooring system is subject to highly cyclic, nonlinear load conditions, mainly induced by the incident waves.

Mooring systems, which may be suitable for WECs, can be categorized into two main configurations: spread mooring and single point mooring. Spread mooring restricts a WEC motion in the horizontal plane and hence will not allow it to weather-vane. This type of mooring may be appropriate for non-directional energy converters. Single point mooring allows a WEC to weather-vane [43-44]. There are several sub-types as listed in Table 2 and it is difficult to define which one is the best without considering the WEC type, location, safety, and cost [45-47]. However, it seems that Catenary Anchor Leg Mooring (CALM) in spread mooring, and Single Anchor Leg Mooring (SALM) in single point mooring are more popular in practical projects [48-49].

Figure 10 shows some commonly used mooring configurations.

\section{V.1. Mooring Requirements}

The mooring could not be considered as an additional cost item in the overall economics of a WEC. It should be designed as an integral element of the overall system that contributes to power extraction efficiency [50-52].

TABLE 2. MOORING TYPES.

\begin{tabular}{ccc}
\hline \hline Type & Spread & Single point \\
\hline \hline Sub-types & $\begin{array}{c}\text { Catenary mooring } \\
\text { Taut mooring } \\
\text { Turret mooring }\end{array}$ & CALM \\
& (Catenary Anchor Leg Mooring) & SALM \\
& (Single Anchor Leg Mooring) \\
& ALC \\
& (Articulated Loading Column) \\
& SPAR \\
& (Single Point Mooring \& Reservoir) \\
& Fixed tower mooring \\
\hline \hline
\end{tabular}




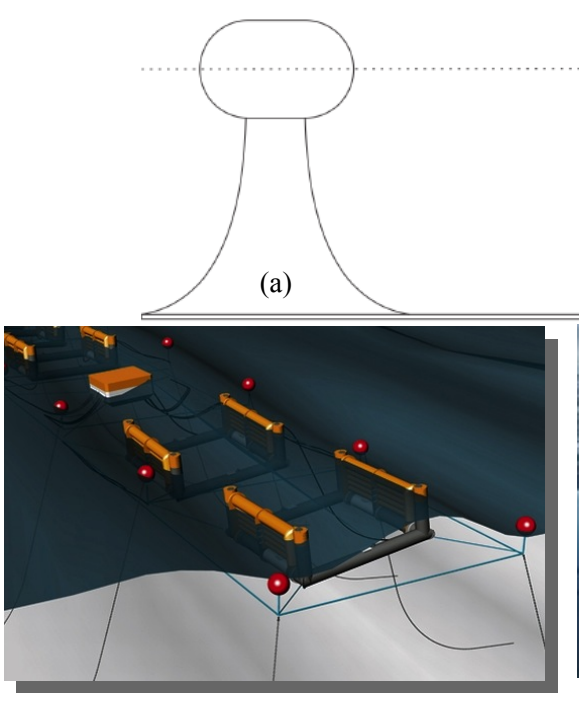

(LANGLEE, NO)

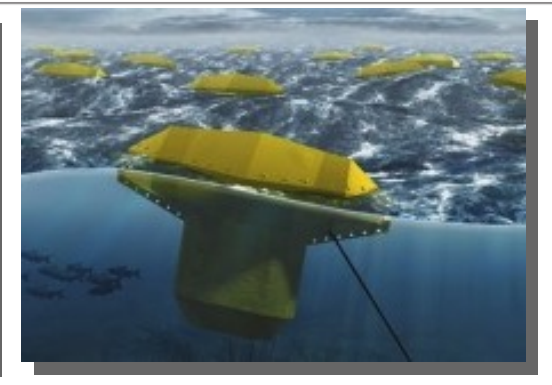

(SEAREV, FR)

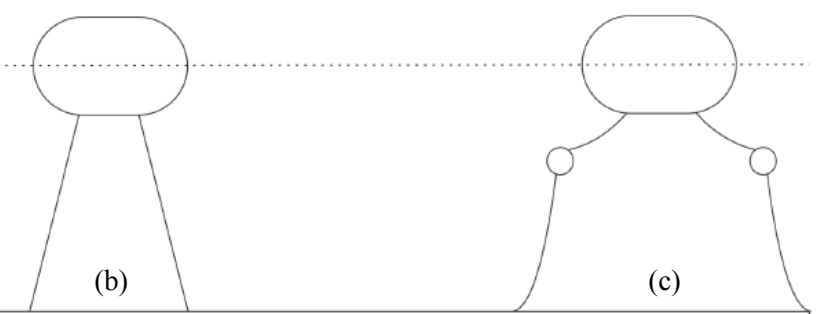

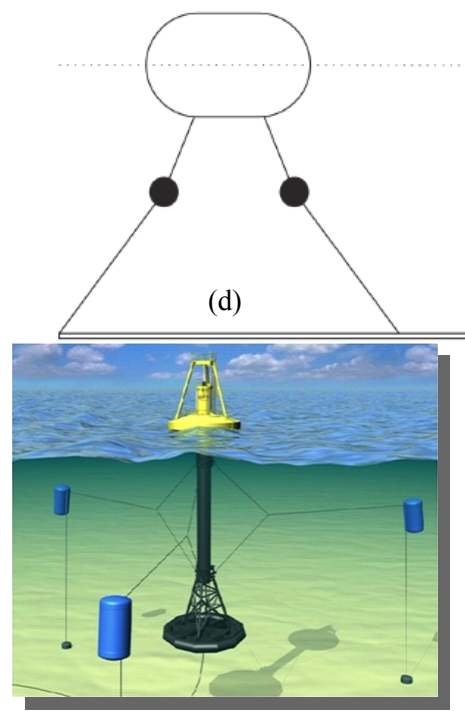

(POWERBUOY, USA)

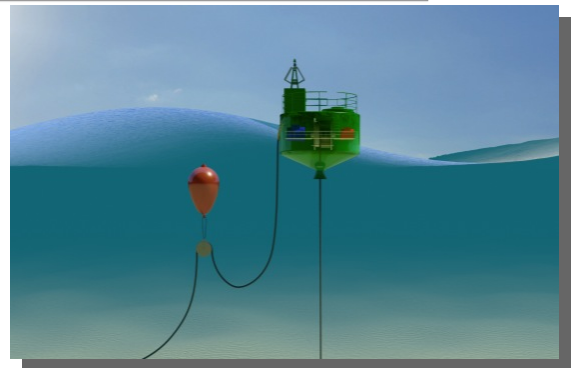

(FLANSEA, BE)

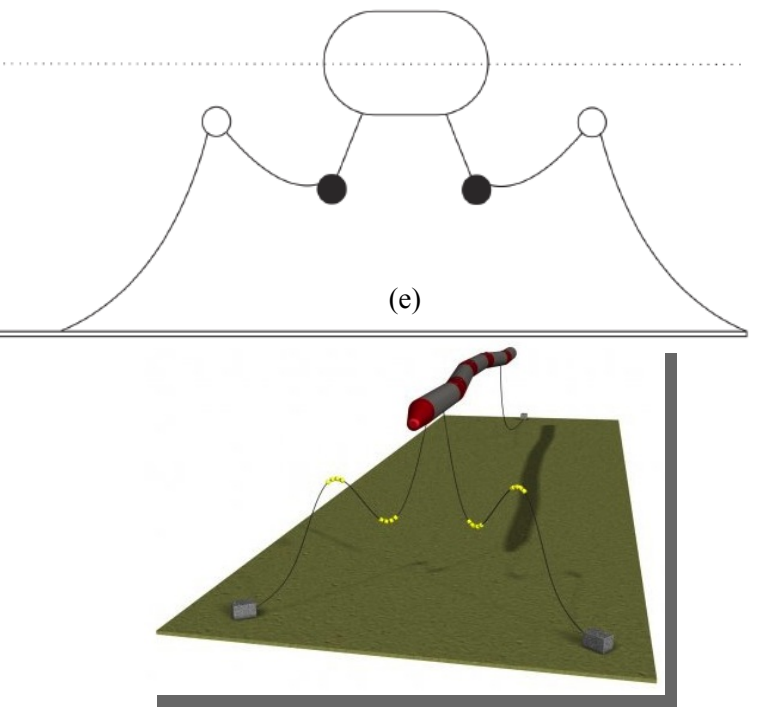

(PELAMIS, UK)

Fig. 10. Typical mooring systems for wave energy converters:

(a) Catenary line; (b) Taut line; (c) Taut line with mid-column float; (d) Taut line with weights, (e) Taut line with weights and floats.

In this context, the following list shows the main requirements that need to be considered for WEC moorings systems (a detailed list could be found in [41]).

- Mooring stiffness is an active element in the wave energy conversion principle used. The mooring system should be sufficiently stiff to:

$\checkmark$ Allow berthing for inspection and maintenance;

$\checkmark$ Station keeping within specified tolerances;

$\checkmark$ Maintain clearance distances between mooring;

$\checkmark$ Avoid constraints in lines and power cable in every tide conditions.

- It should be sufficiently compliant to the environmental loading to reduce the forces acting on anchors, mooring lines and the device itself to a minimum.

- It should be sufficient to accommodate the tidal range at the installation location.
It is therefore obvious that mooring design is a critical part of a WEC project. The devices are generally thought to be used in areas of demanding environmental loads due to waves, current and wind. These survivability issues are addressed in existing offshore standards, such as the DNV-OSE301 [53].

\section{Challenges for Commercial Viability}

It has been proven that wave energy extraction is very attractive as it is spatially more concentrated than both wind and solar energy; it is also more persistent and predictable than wind energy. On the other hand, the development, from concept to commercial stage, has been found to be a very slow and expensive process [11], [54]. Indeed, it is difficult to follow what was done in the wind turbine industry where at first, small machines where developed first, and were subsequently scaled-up 
to larger sizes and powers for massive deployment. In fact, optimal wave energy absorption involves some kind of resonance. This implies that WECs geometry and size are linked to wavelength. So, if pilot plants are to be tested in the open ocean, they must be large structures [6].

In this specific context, challenges that WECs should to overcome to become commercially competitive leading to massive deployment could be summarized as:

- As for offshore converters, WECs should withstand extreme wave condition leading to difficult and costly maintenance operations.

- As above discussed, mooring design is a critical part. In addition to the demanding environmental loads due to waves, current and wind, the mooring system should also withstand constraints due to the WEC alignment for capture optimization. Given the continuous environmental loading, fatigue has been identified as one of the key engineering challenges [55]. In addition, marine growth and corrosion need to be considered [56].

- Higher costs of construction, deployment, and maintenance need to be supported with substantial financial support from governments.

Regarding mooring fatigue and cost issues, it has been recently suggested to develop WECs without mooring [57-58]. The developed converter has station-keeping ability and evasive maneuver by diving. For stationkeeping within a uniform bound, a wave glider has been adopted as propulsion system [59] (Fig. 11). In addition, such kind of system has the ability to submerge to a certain depth for its safety in emergency condition such as typhoon [60].

\section{Conclusion}

This paper has proposed an up-to-date review of the most recent trends regarding main wave energy converter technologies with respect to overviews already published in the past years. In addition, mooring has been discussed and has been shown to be a key feature behind massive deployment of wave energy converters. Finally it has been highlighted some challenges that needs to be overcome to enlarge the vision of large-scale commercial arrays of wave energy converters.

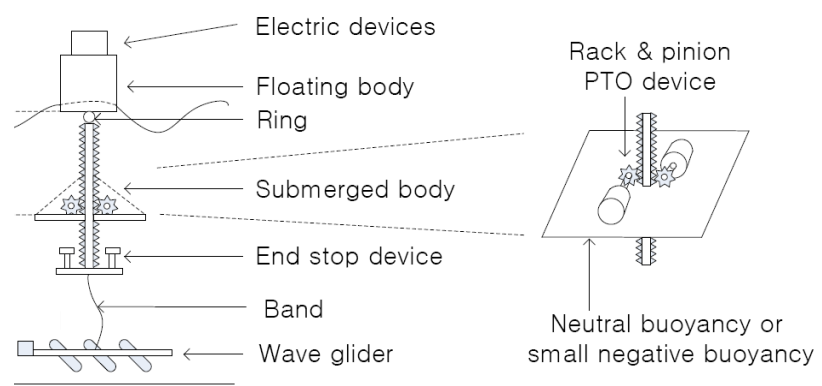

Fig. 11. A mooring-less wave energy converter concept [57].

\section{References}

[1] J. Crus Ed., Ocean Wave Energy: Current Status and Future Perspectives. Springer, Berlin, 2008.

[2] J.G. Vining and A. Muetze, "Economic factors and incentives for ocean wave energy conversion," IEEE Trans. Industry Applications, vol. 45, n², pp. 547-554, March-April 2009.

[3] Z. Zhou, F. Scuiller, J.F. Charpentier, M.E.H. Benbouzid and T. Tang, "An up-to-date review of large marine tidal current turbine technologies," in Proceedings of the 2014 IEEE PEAC, Shanghai (China), pp. 448-484, November 2014.

[4] S. Benelghali, M.E.H. Benbouzid and J.F. Charpentier, "Marine tidal current electric power generation technology: State of the art and current status," in Proceedings of the 2007 IEEE IEMDC, Antalya (Turkey), vol. 2, pp. 1407-1412, May 2007.

[5] D. Ross, Power from the Waves. Oxford University Press: 1995.

[6] F.A.O. Falcao, "Wave energy utilization: A review of the technologies," Renewable and Sustainable Energy Reviews, vol. 14, n³, pp. 899-918, April 2010.

[7] H. Titah-Benbouzid and M.E.H. Benbouzid, "Ocean wave energy extraction: Up-to-date technologies review and evaluation," in Proceedings of the 2014 IEEE PEAC, Shanghai (China), pp. 338342, November 2014.

[8] M.S. Lagoun, A. Benalia and M.E.H. Benbouzid, "Ocean wave converters: State of the art and current status," in Proceedings of the 2010 IEEE ENERGYCON, Manama (Bahraïn), pp. 636-642, December 2010 .

[9] Y. Hong, R. Waters, C. Boström, M. Eriksson, J. Engström and M. Leijon, "Review on electrical control strategies for wave energy converting systems," Renewable and Sustainable Energy Reviews, vol. 31, pp. 329-342, March 2014.

[10] I. Lopez, J. Andreu, S. Ceballos, I. Martínez de Alegria and I. Kortabarria, "Review of wave energy technologies and the necessary power-equipment," Renewable and Sustainable Energy Reviews, vol. 27, pp. 413-434, November 2013.

[11] B. Czech and P. Bauer, "Wave energy converter concepts: Design challenges and classification," IEEE Industrial Electronics Magazine, vol. 6, n², pp. 4-16, June 2012.

[12] B. Drew, A.R. Plummer and M.N. Sahinkaya, "A review of wave energy converter technology," Proc. IMechE, Part A: Journal Power and Energy, vol. 223, n8, pp. 887-902, December 2009.

[13] J. Falness, "A review of wave-energy extraction," Marine Structures, vol. 20, n 4 , pp. 185-201, October 2007.

[14] S. Olaya, J.M. Bourgeot and M.E.H. Benbouzid, "Hydrodynamic coefficient computation for a partially submerged wave energy converter," IEEE Journal of Oceanic Engineering, vol. PP, n 99 , pp. 1-14, 2014.

[15] S. Olaya, J.M. Bourgeot and M.E.H. Benbouzid, "Optimal control for a self-reacting point absorber: A one-body equivalent model approach," in Proceedings of the 2014 IEEE PEAC, Shanghai (China), pp. 332-337, November 2014.

[16] S. Olaya, J.M. Bourgeot and M.E.H. Benbouzid, "Modelling and preliminary studies for a self-reacting point absorber WEC," in Proceedings of the 2014 IEEE ICGE, Sfax (Tunisia), pp. 14-19, March 2014.

[17] K. Rhinefrank et al., "Comparison of direct-drive power takeoff systems for ocean wave energy applications," IEEE Journal of Oceanic Engineering, vol. 37, n`1, pp. 35-44, January 2012.

[18] T.K.A. Brekken, H.M. Hapke, C. Stillinger and J. Prudell, "Machines and drives comparison for low-power renewable energy and oscillating applications," IEEE Trans. Energy Conversion, vol. 25, n4, pp. 1162-1170, December 2010.

[19] L. Cappelli, F. Marignetti, G. Mattiazzo, E. Giorcelli, G. Bracco, S. Carbone, C. Attaianese, "Linear tubular permanent-magnet generators for the inertial sea wave energy converter," IEEE Trans. Industry Applications, vol. 50, n³, pp. 1817-1828, May/June 2014.

[20] C. Boström, B. Ekergard, R. Waters, M. Eriksson and M. Leijon, "Linear generator connected to a resonance-rectifier circuit," IEEE Journal of Oceanic Engineering, vol. 38, n², pp. 255-262, April 2013.

[21] T.K.A. Brekken, K. Rhinefrank, A. von Jouanne, A. Schacher, J. Prudell and E. Hammagren, "Scaled development of a novel wave 
energy converter including numerical analysis and high-resolution tank testing," Proc. IEEE, vol. 101, n²4, pp. 866-875, April 2013.

[22] R. Vermaak and M.J. Kamper, "Design aspects of a novel topology air-cored permanent magnet linear generator for direct drive wave energy converters," IEEE Trans. Industrial Electronics, vol. 59, n5, pp. 2104-2115, May 2012.

[23] N. Hodgins, O. Keysan, A.S. McDonald and M.A. Mueller, "Design and testing of a linear generator for wave-energy applications," IEEE Trans. Industrial Electronics, vol. 59, n 5 , pp. 2094-2103, May 2012

[24] J. Zhang, H. Yu, Q. Chen, M. Hu, L. Huang and Q. Liu, "Design and experimental analysis of AC linear generator with Halbach PM arrays for direct-drive wave energy conversion," IEEE Trans. Applied Superconductivity, vol. 24, n³, \#0502704, June 2014.

[25] R. Ekström, B. Ekergård and M. Leijon, "Electrical damping of linear generators for wave energy converters-A review," Renewable and Sustainable Energy Reviews, vol. 42, pp. 116-128, February 2015.

[26] H. Polinder, B.C. Mecrow, A.G. Jack, P.G. Dickinson and M.A. Mueller, "Conventional and TFPM linear generators for directdrive wave energy conversion," IEEE Trans. Energy Conversion, vol. 20, no. 2, pp. 260-267, June 2005.

[27] M.A. Mueller, "Electrical generators for direct drive wave energy converters," IEE Proc. Generation, Transmission \& Distribution, vol. 149, n 4 , pp. 446-456, July 2002.

[28] N. Muller, S. Kouro, J. Glaria and M. Malinowski, "Mediumvoltage power converter interface for WaveDragon wave energy conversion system," in Proceedings of the IEEE ECCE, Denver (USA), pp. 352-358, September 2013.

[29] M.S. Lagoun, A. Benalia, and M.E.H. Benbouzid, "A predictive power control of doubly fed induction generator for wave energy Converter in irregular waves," in Proceedings of the 2014 IEEE ICGE, Sfax (Tunisia), pp. 26-31, March 2014.

[30] M.S. Lagoun, S. Nadjem, A. Benalia and M.E.H. Benbouzid, "Predictive power control of doubly-fed induction generator for wave energy converters," in Proceedings of the 2012 EFEA (International Symposium on Environment Friendly Energies and Applications), Newcastle upon Tyne (UK), pp. 312-317, June 2012.

[31] M. Alberdi, M. Amundarain, A.J. Garrido and I. Garrido, "Neural control for voltage dips ride-through of oscillating water columnbased wave energy converter equipped with doubly-fed induction generator," Renewable Energy, vol. 48, pp. 16-26, 2012.

[32] M. Alberdi, M. Amundarain, A.J. Garrido, I. Garrido and F.J. Maseda, "Fault-ride-through capability of oscillating-watercolumn-based wave-power-generation plants equipped with doubly fed induction generator and airflow control," IEEE Trans. Industrial Electronics, vol. 58, n5, pp. 1501-1517, May 2011.

[33] S. Benelghali, M.E.H. Benbouzid and J.F. Charpentier, "Generator systems for marine current turbine applications: A comparative study," IEEE Journal of Oceanic Engineering, vol. 37, n³, pp. 554-563, July 2012.

[34] E.V Sanchez, R.H. Hansen and M.M. Kramer, "Control performance assessment and design of optimal control to harvest ocean energy," IEEE Oceanic Engineering, vol. 40, n 1 , pp. 1526, January 2015.

[35] J. Aubry, H. B. Ahmed, B. Multon, "Sizing optimization methodology of a surface permanent magnet machine-converter system over a torque-speed operating profile: application to a wave energy converter," IEEE Trans. Industrial Electronics, vol. 59, n5, pp. 2116-2125, May 2012.

[36] A. Babarit, J. Hals, M.J. Muliawan, A. Kurniawan, T. Moan, J. Krokstad, "Numerical benchmarking study of a selection of wave energy converters," Renewable Energy, vol. 41, pp. 44-63, May 2012.

[37] L. Margheritini, D. Vicinanza and P. Frigaard, "SSG wave energy converter: Design, reliability and hydraulic performance of an innovative overtopping device," Renewable Energy, vol. 34, n5, pp. 1371-1380, May 2009.

[38] Vryhof Anchors: http://www.vryhof.com/ammanual.htm

[39] I.M.L. Ridge, S.J. Banfield and J. Mackay, "Nylon fibre rope moorings for wave energy converters," in Proceedings of the 2010 MTS/IEEE OCEANS, Seattle (USA), pp. 1-10, September 2010.

[40] J.D. Pasternak, M. Hersley and S. Leite, "Increased offshore MODU mooring performance through MODUline ${ }^{\circledR}$ polyester rope," in Proceedings of the 2010 MTS/IEEE OCEANS, Seattle (USA), pp. 1-8, September 2010.

[41] R.E. Harris, L. Johanning and J. D. Wolfram, "Mooring systems for wave energy converters: a review of design issues and choices," in Proceedings of the 2004 MAREC, Blyth (UK), pp. 110, July 2004.

[42] Bruce Connector: http:// www.bruceanchor.co.uk/

[43] P.R. Thies, L. Johanning and P. McEvoy, "A novel mooring tether for peak load mitigation: Initial performance and service simulation testing," International Journal of Marine Energy, vol. 7, pp. 43-56, September 2014.

[44] M. Tavakoli, T.K.A. Brekken, B. Bosma and A.A. Schacher, "programmable mooring controller for tank testing of scaled wave energy converters," in Proceedings of the 2013 IEEE PES General Meeting, Vancouver (Canada), pp. 1-5, July 2013.

[45] L. Johanning, G.H. Smith and J. Wolfram, "Mooring design approach for wave energy converters," Proc. Inst. Mech. Eng., Part M: Journal of Engineering for the Maritime Environment, vol. $220, n^{\circ} 4$, pp. 159-174, December 2006.

[46] L. Johanning, G.H. Smith and J. Wolfram, "Measurements of static and dynamic mooring line damping and their importance for floating WEC devices," Ocean Engineering, vol. 34,n¹4-15, pp. 1918-1934, 2007.

[47] Z. Gao and T. Moan, "Mooring system analysis of multiple wave energy converters in a farm configuration," in Proceedings of the 2008 EWTEC, Uppsala (Sweden), pp. 509-518, September 2009.

[48] A. Pecher, A. Foglia and J.P. Kofoed, "Comparison and sensitivity investigations of a CALM and SALM type mooring system for wave energy converters," Journal of Marine Science and Engineering, vol. 2, pp. 93-122, 2014.

[49] H. Ming, and G. A. Aggidis, "Developments, expectations of wave energy converters and mooring anchors in the UK," Journal of Ocean University of China, vol. 7, $\mathrm{n}^{\circ} 1$, pp. 10-16, February 2008.

[50] F. Cerveira, N. Fonseca and R. Pascoal, "Mooring system influence on the efficiency of wave energy converters," International Journal of Marine Energy, vol. 3-4, pp. 65-81, December 2013.

[51] B. Zanuttigh, E. Angelelli and J.P. Kofoed, "Effects of mooring systems on the performance of a wave activated body energy converter," Renewable Energy, vol. 57, pp. 422-431, September 2013.

[52] W. Valentine and K.D. von Ellenrieder, "Model scaling of ocean hydrokinetic renewable energy systems," IEEE Journal of Oceanic Engineering, vol. 1, n ${ }^{\circ}$, pp. 27-36, January 2015.

[53] Det Norske Veritas offshore standard DNV-OS-E301, Position Mooring, October 2010.

[54] G. Beaudoin, D. Robertson, R. Doherty, D. Corren, B. Staby and L. Meyer, "Technological challenges to commercial-scale application of marine renewables," Oceanography, vol. 23, $\mathrm{n}^{\circ} 2$, pp. 32-41, June 2010.

[55] P.R. Thies, L. Johanning, V. Harnois, H.C.M. Smith and D.N. Parish, "Mooring line fatigue damage evaluation for floating marine energy converters: Field measurements and prediction," Renewable Energy, vol. 63, pp. 133-144, March 2014.

[56] B. Polagye and J. Thomson, "Screening for biofouling \& corrosion of tidal energy device materials," Northwest National Marine Renewable Energy Center, Oregon State University, Report 1, April 2010.

[57] H. Joe, M. Kim, S.M. Wi, H.S. Kwon and S.C. Yu, "Development of mooring-less robotic buoy system using wave powered renewable energy," in Proceedings of the 2014 MTS/IEEE OCEANS, Newfoundland (Canada), pp. 1-6, September 2014.

[58] M. Kim, S.M. Wi, H. Joe, H.S. Kwon and S.C. Yu, "Multi-body point absorber system without a mooring," in Proceedings of the 2014 MTS/IEEE OCEANS, Taipei (Taiwan), pp. 1-4, April 2014.

[59] R. Hine, S. Willcox, G. Hine and T. Richardson, "The Wave Glider: A Powered autonomous marine vehicle," in Proceedings of the 2009 MTS/IEEE OCEANS, Biloxi (USA), pp. 1-6, October 2014.

[60] J.S. Lee and S.C. Yu, "Preliminary study of long endurance moorless non-drifting buoy," in Proceedings of the 2013 IEEE IUTS, Tokyo (Japan), pp. 1-6, March 2013. 
${ }^{1}$ University of Brest, EA 4325 LBMS, Rue de Kergoat, CS 93837, 29238 Brest Cedex 03, France (e-mail: hosna.titahbenbouzid@gmail.com, Mohamed.Benbouzid@univ-brest.fr).

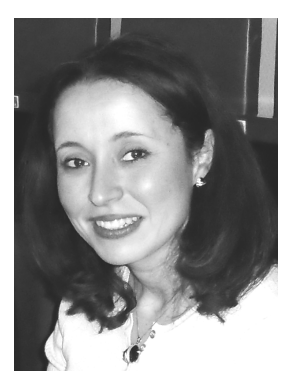

Hosna Titah-Benbouzid was born in Annaba, Algeria, in 1973. She received the Engineer degree in agro-alimentary engineering from the University of Constantine, Constantine, in 1998, the M.Sc. degree in environment engineering from the University of Picardie, Amiens, France, in 2006, and the PhD degree in Chemical and Environmental engineering from the University of Brest, Brest, France, in 2010.

Dr. Titah-Benbouzid is an affiliate member of the LBMS Lab (EA 4325) since 2012. Her current research interests are marine renewable energy systems interactions with marine environment and biofouling.

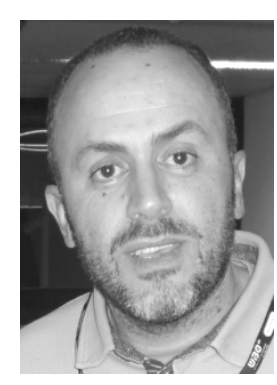

Mohamed El Hachemi Benbouzid was born in Batna, Algeria, in 1968. He received the B.Sc. degree in electrical engineering from the University of Batna, Batna, Algeria, in 1990, the M.Sc. and Ph.D. degrees in electrical and computer engineering from the National Polytechnic Institute of Grenoble, Grenoble, France, in 1991 and 1994, respectively, and the Habilitation à Diriger des Recherches degree from the University of Picardie "Jules Verne," Amiens, France, in 2000.

After receiving the Ph.D. degree, he joined the Professional Institute of Amiens, University of Picardie "Jules Verne," where he was an Associate Professor of electrical and computer engineering. Since September 2004, he has been with the Institut Universitaire de Technologie of Brest, University of Brest, Brest, France, where he is a Professor of electrical engineering. His main research interests and experience include analysis, design, and control of electric machines, variable-speed drives for traction, propulsion, and renewable energy applications, and fault diagnosis of electric machines.

Prof. Benbouzid is an IEEE Senior Member. He is the Editor-inChief of the INTERNATIONAL JOURNAL ON ENERGY CONVERSION (IRECON). He is also an Associate Editor of the IEEE TRANSACTIONS ON ENERGY CONVERSION, the IEEE TRANSACTIONS ON INDUSTRIAL ELECTRONICS, the IEEE TRANSACTIONS ON SUSTAINABLE ENERGY, and the IEEE TRANSACTIONS ON VEHICULAR TECHNOLOGY. He was an Associate Editor of the IEEE/ASME TRANSACTIONS ON MECHATRONICS from 2006 to 2009. 